\title{
In quest of the longest-lasting and most annoying pain for patients and for dentists. Quantitative and qualitative characteristics of temporomandibular myofascial pain dysfunction syndrome - a questionnaire study
}

\section{BACKGROUND}

Dysfunctions in the face, due to the psychological importance of the structures in the face and head, have long been a subject of interest for researchers exploring issues concerning health-related quality of life. The surprising results of previous clinical trials for myofascial pain dysfunction syndrome of the temporomandibular joints encouraged the present authors to plan a study focused on obtaining systematic knowledge of the issue.

\section{PARTICIPANTS AND PROCEDURE}

The study included 26 patients of the Masticatory System Disorders Laboratory of the Dental Prosthetic Clinic at the Jagiellonian University Medical College diagnosed with the painful form of muscle-related functional masticatory organ disorders. The study was part of a larger research project. The data to be analysed for this article was obtained in the course of a single questionnaire survey conducted prior to the start of the treatment process.

\section{RESULTS}

The results showed the quantitative characteristics of pain experiences in the clinical group, observed in the context of the circadian dynamics, psychophysical factors, and the location of pain, as well as their quality characteristics. The analyses showed negative covariances of the quality of life perceived by patients and the length of periods without pain, pain intensifying factors, and emotional image of pain. The strongest pain experienced by the patients negatively correlated with the quality of life related to the sphere of physical pain and mental distress, whereas the weakest pain correlated with the quality of life related to the social sphere. The lower quality of life occurred together with the frontal, zygomatic, mental, parotideomasseteric, and occipital region.

\section{CONCLUSIONS}

It is necessary to further analyse the issue on a larger sample in order to explain and clarify the obtained results.

\section{KEY WORDS}

chronic pain; temporomandibular disorders; myofascial pain syndrome; psychostomatology

ORganisation - 1: Medical Psychology Unit, Department of Psychiatry, Jagiellonian University Collegium Medicum,

Krakow, Poland · 2: Department of Psychology, University of Social Sciences and Humanities, Poznan, Poland

- 3: University of Social Sciences and Humanities Katowice Division, Katowice, Poland - 4: Consulting Room of

Functional Disorders of Masticatory Organs, Department of Dental Prosthetics, Jagiellonian University Medical

College, Krakow, Poland · 5: Faculty of Health Sciences, Department of Health Psychology, Jagiellonian University

Medical College, Krakow, Poland · 6: Consulting Room of Psychology, Department of General, Oncological, and

Gastroenterological Surgery, Jagiellonian University Medical College, Krakow, Poland

aUthors' Contributions - A: Study design - B: Data collection - C: Statistical analysis - D: Data interpretation .

E: Manuscript preparation · F: Literature search · G: Funds collection

CORRESPONDING AUthor - Joanna M. Biegańska-Banaś, Department of Psychiatry, Jagiellonian University Collegium

Medicum, 21 A Kopernika Str., 31-501 Krakow, Poland, e-mail: bieganskajm@gmail.com

to Cite this ARTICle - Biegańska-Banaś, J. M., Gierowski, J. K., Ferendiuk, E., Pihut, M., \& Adamczyk, K. (2018). Health

Psychology Report, 6(3), 222-242. doi: https://doi.org/10.5114/hpr.2018.75860

RECEIVED 11.07.2017 · REVIEWED · 18.11.2017 · ACCEPTED 1.02.2018 · PUBLISHED 17.05.2018 


\section{BACKGROUND}

\section{THE SIGNIFICANCE OF FACIAL PAIN EXPERIENCES ON THE PSYCHO-EMOTIONAL FUNCTIONING OF A PERSON}

As stated by the International Association for the Study of Pain (IASP, 1994), pain should be seen as a psychosomatic phenomenon, i.e. in relation to its somatic sphere (sensation), psychological sphere (taking into account a cognitive and emotional component), and, connecting these two areas, the psychosomatic sphere (including a behavioural component). According to this reasoning, pain sensations are determined by a number of factors present both in the pain itself, its specificity and quality, and in the patient, their opinions about pain, previous experiences of pain, emotional assessment of pain situations, personality traits, or their structure (Ortenburger, 2008; Suchocka, 2008). Thus, pain located in different regions and having different aetiopathogenesis, although always inextricably linked with suffering, has a different psychological significance to a given person. Pain, especially chronic pain, experienced in the area of the mouth and face, seems to be all the more acute as it affects basic human activities, such as food intake or communication.

Due to the fact that the mouth and face are involved in these types of activities, the facial parts, with particular emphasis on the masticatory organ, can be considered key structures relevant to human survival. Their damage, often signalised by pain, prevents free food intake and often requires the help of another person, thus posing a threat to life, which in turn, raises legitimate fear in the patient, usually subconsciously (Eliasz, 2004). Such situations have further psychological consequences. Constant deprivation of physiological needs not only causes psychophysical discomfort, but also makes their satisfaction the primary driving force of human activities, resulting in the person's lack of interest in meeting higher-level needs (safety, love and belonging, esteem needs, and finally, self-actualisation). It also increases the sense of loss of control, affects dysregulation, or causes symptoms of anhedonia related to the loss of a number of sensory experiences (Maslow, 2013; Okeson, 2014; Patel \& Schlundt, 2001; Ziółkowska, 2009; Ziółkowska \& Mroczkowska, 2012). The mouth and face are also basic structures in the process of interpersonal communication, not only verbal but also non-verbal, expressed through facial expressions or eye contact between people participating in face-to-face interactions. The face can express as well as read expectations and opinions to build satisfying and meaningful relationships because it is a valuable source of information about the health and well-being of an individual. Social psychologists have pointed out that the face is more important in building interpersonal relationships than the first impression (which is nonetheless based on the face) (Asch, 1946; Oosterhof \& Todorov, 2008; Vernon, Sutherland, Young, \& Hartley, 2014). Thus, any experiences of pain in the face or mouth, especially in chronic form, threaten not only the possibility of effective, but also psychosocially satisfactory, interpersonal communication for the patient. These can result from a number of cognitive, emotional, and behavioural disorders linked to the experience of particularly severe and/or chronic pain (Engel, 1959; Flor \& Turk, 2006; Gamsa, 1990). Therefore, the person who experiences pain within the craniofacial structures faces verification of their body image as a consequence; in other words, the way of self-perceiving, which in turn is an important component of the so-called self-image, is relevant to general well-being (Schwartz \& Brownell, 2004). Distortion, asymmetry, and grimaces of pain noticeable in the appearance of the face, which might be caused by the evolution of masticatory organ dysfunctions, modify self-perception, contributing to considerable distress and mental strain. The change in self-perception is confirmed by the results of research in psychodermatology, indicating that patients with visible lesions in the face often suffer from depressive disorders with predominant symptoms of low self-esteem and mood as well as social withdrawal (Golchai et al., 2010; Ȯztürk, Deveci, Bağcioğlu, Atalay, \& Serdar, 2013).

There are many psychological theories indicating the relationship between personality traits (understood in the terms of the emotional-cognitive-behavioural pattern) and life experiences, which influence the easiness of pain response to favourable factors and reinforce these responses to chronic conditions. Psychoanalysis is the concept that devotes a lot of attention to the facial region in this context, trying to relate all kinds of dysfunctions in this particular body region with disturbed psychosexual development. According to this concept, dysfunctions within the masticatory organ, as well as the way of experiencing pain related to them, are inextricably linked to the so-called oral stage of human development. This stage refers to the earliest period of human development, when one's first impulsive needs (such as hunger) are satisfied with work of the muscles in the region of the head, and above all, the muscles of the masticatory apparatus (Freud, 2011). Excessive needs deprivation in this period, e.g. related to early childhood diseases, physical or emotional absence of a parent, or a violent family situation, makes it easier for a person to respond with anger to the difficulties of everyday life while having difficulties expressing it. This is considered an important factor in the aetiological image of pain from masticatory organ dysfunctions (Mutlu, Herken, Güray, Öz, \& Kalayci, 2002;
Psychology of TMJPDS 
Thaller, Vrkljan, Hotujac, \& Thakore, 1999; Von Korff, 1999). Interference in the course of oral stage development may also lead to a variety of disturbances within the masticatory organ, including impaired articulation of speech and the development of parafunctional habits within the masticatory organ (Nunberg, 1968; Shahraki, Yassaei, \& Goldani, 2012). Experiencing pain secondary to masticatory organ dysfunctions in this group of patients appears to result in further psychological consequences, such as increased predisposition to react with sadness or increased irritability manifested in behaviour (Vickers \& Boocock, 2005). The causes can be traced back to the characteristics of the pain experiences themselves, inscribed in the image of masticatory organ dysfunctions.

\section{THE EXPERIENCES OF PAIN CHARACTERISTICS IN MASTICATORY ORGAN DYSFUNCTIONS}

Pain inscribed in the masticatory organ dysfunctions is described, as proposed by the IASP (1994), as so-called myofascial pain dysfunction syndrome of the masticatory system (MPDS). Its diagnostic criteria include severe pain experiences, chronic or restricted to performing functional movements, and is often associated with limitation of movement of the jaw and acoustic effects when starting to use the temporomandibular joints. The concept was formed indicating that pain has a central place in the clinical image of this disorder (Laskin, 1969; Prusiński, 1996; Schwartz, 1959; Voss, 1964). Moreover, it seems that the presence of the experience of pain is more important than its intensity, which in fact appears to be higher for patients who experience pain due to the isolated parafunction of bruxism (excessive teeth grinding or jaw clenching), as well as for patients experiencing any sort of chronic pain (Dao, Lund, \& Lavigne, 1994). The intensity of pain in MPDS is usually estimated at a value of 3-5 out of $10 \mathrm{~cm}$ on the visual analogue scale (VAS) (Bal \& Celiker, 2009). What is characteristic of the general dynamics of the persistence of these kinds of experiences of pain is the fact that their level in these patients, who have been diagnosed correctly and subjected to adequate treatment, decreases at a significant rate; a significant reduction of pain is observed approximately one to two weeks after the start of treatment (Eliasz, 2004; Kino et al., 2005; Oliveira, 2005; Oliveira et al., 2003a; Van Grootel et al., 2005). However, whether or not the results obtained during therapy persist is debatable in this case. Lack of proper diagnostic and therapeutic activities may, in turn, cause the pain to consolidate, at the same time becoming less susceptible to traditional forms of treatment (Dworkin \& LeResche, 1993; Dworkin \& Massoth, 1994).

Today, attention is drawn to the diverse nature of the experiences of pain in the course of masticatory organ dysfunctions, related to their different pathomechanisms: musculoskeletal, skeletal, or muscular. Emphasis is put on the diversified characteristics, both quantitative and qualitative, of pain experiences depending on the aetiology of dysfunctions within the masticatory organ. According to the IASP (1994), when the bone is a significant component of the experience of pain, the patient usually describes the pain as sharp, acute, and penetrating. It is usually located in the temporomandibular joint and surrounding tissues. The pain is closely linked to chewing activities and is, typically, susceptible to analgesia using non-steroidal anti-inflammatory drugs. On the other hand, when the major contribution to pain is a muscle factor, it is characterised as diffuse and dull. Pain related to other anatomo-physiological areas is heterotopic; however, it is most frequently localised in the masseter muscles and muscle structures located around the ears. The most painful areas for patients seem to be ears, mandible/maxilla, and temples. Relevant mechanisms of pain include intraoral, jaw, supraorbital, and auriculotemporal regions, depending on the involved muscles and the intensity of the experiences of pain (Fricton et al., 1985; Simons, Travell, \& Simons, 1999; Svensson \& Graven-Nielsen, 2001; Wright, 2000). In cases when muscle is a significant component of pain, the region indicated by the patient might be different from the real source of pain. This type of pain is characterised by so-called "trigger points", which are hyperirritable muscle tissue groups (Travell \& Simons, 1983). The previously mentioned study by Oliveira et al. (2003a) showed a significant correlation between the intensity of the experience of pain and the location of these trigger points. Therefore, when patients experience intense pain, the most painful area appears to be temporal, whereas in the case of moderate pain it is the region of the neck.

The emotional description of the pain experienced by patients who suffered from masticatory organ dysfunctions completes the characteristics of the experiences of pain within this group of patients. A few studies focused on this issue have shown significant differences concerning affective descriptions, which depend on the aetiological mechanism of dysfunctions. It was found that patients who suffer from a muscle-related functional masticatory organ disorder show significantly more emotional categories of the experiences of pain than patients who suffer from a bone-related form of these disorders (Mongini \& Italiano, 2001). Importantly, the analysis of the terms chosen by the subjects to describe experienced ailments indicated that these terms vary depending on the experienced problem. In the case of muscle pain, patients often describe it as exhausting and intrusive (Watanabe et al., 2005). However, it turns out that differences in this respect, depending on the predominant pathomechanism of the disorder, might 
be greater and localisation-related. Pihut et al. (Pihut, Szewczyk, Wiśniewska, \& Gala, 2012) showed that there are some differences in the description of pain experiences by patients diagnosed with displacement of the articular disc (thus, bone-related) and by those with no apparent dysfunction of this type; in the first case, the patients' descriptions were significantly more emotional. The analysis of the data suggests a different level of comfort of everyday functioning of the patients, depending on the kind of experience of pain. Health-related quality of life is a construct that should include, among others, the psycho-emotional aspect of patient function.

\section{PAIN IN FUNCTIONAL DISORDERS OF THE MASTICATORY ORGAN AND HEALTH- RELATED QUALITY OF LIFE}

The concept of "quality of life" was introduced into medicine in the 1970 s, referring in its form to social sciences. According to the World Health Organisation's definition, quality of life covers almost all aspects of human life, understood as an "individual's perception of their position in life in the context of the culture and value systems in which they live and in relation to their goals, expectations, and standards determined by features of their environment" (1995, p. 1403). Therefore, today quality of life can be defined as an "individual's comprehensive evaluation of their physical health, psychological state, social relationships, level of autonomy and independence from other people, personal beliefs and convictions" (Tobiasz-Adamczyk, 1996, p. 36). Determined by the state of health, occurring diseases, and the natural aging process, it is based on a multidimensional concept of health-related quality of life (HRQOL). The concept was introduced by Schipper et al. (Schipper, Clinch, \& Olweny, 1996), who defined it as "a functional effect of the disease and consequences of treatment perceived (experienced) by the patient".

There are many concepts that take different components of this definition of quality of life into account. For example, Siegrist and Junge (1989) point to three interrelated aspects: physical conditions (loss of performance, the presence of pain), psychological (depression, anxiety, mental state), and social (social isolation, behaviour during disease). Künsbeck et al. (1990) further developed this concept by dividing the components of quality of life into subjective ones, which categorised all the components addressed by Siegrist and Junge plus the interpersonal aspect (social support, interpersonal conflicts, interpersonal relations) as well as the objective ones, including the state of health evaluated on the basis of laboratory test results, psychopathological diagnosis, and socio-economic status (Tobiasz-Adamczyk, 2000). As noted by Tobiasz-Adamczyk (2006), a constantly pro- gressive increase in interest in health-related quality of life concerns groups of patients experiencing various diseases. Inclusion of emotional experiences, mental state, and the ability to function in everyday life in the biological assessment of health seems to be particularly important in the context of these diseases, in which recovery is temporary or incomplete. It appears that functional disorders of the masticatory organ can be considered a disease of this kind.

As a disorder in the stomatognathic system, masticatory organ dysfunctions are considered in the context of the concept of oral health-related quality of life. Oral health, as indicated by Dolan (2013), is a state of comfortable and functional dentition, which allows an individual to fulfil their social roles. A broader definition was formed by, among others, the Canadian Dental Association (2001), whose members defined oral health as a state in which the oral cavity and related tissues and structures positively affect physical, mental, and social well-being, and allow an individual to speak, intake food, and participate in social life unhindered by pain, discomfort, or embarrassment. Oral health-related quality of life should be considered a multidimensional concept that changes over time. Similarly to the health-related quality of life, there are many definitions of the above-mentioned concept. For example, Inglehart and Bagramian (2002) distinguish physical functioning and the presence of pain, but also social and psychological aspects within the concept. In contrast, Sischo and Broder (2011) believe that the oral health-related quality of life perceived by patients is affected by the following factors: oral cavity health, functioning, environment, emotional and social factors, and satisfaction with treatment. A conceptual framework for measuring the oral health-related quality of life was formulated by Locker (1988), who tried to include all the possible functional and psychosocial consequences of oral cavity diseases in it. People who suffer from disorders in the stomatognathic system are, by definition, experiencing damage to the body. When these changes are extensive, they lose the ability to perform everyday activities, such as speaking freely or eating certain kinds of food, which indicates a functional limitation that, in consequence, leads to disability. As a result, the above-mentioned issues limit readiness to function in social relations, resulting in impairment. It is more likely for a disability to occur simultaneously with functional limitation and discomfort, whereas impairment is most likely to occur when disability, discomfort, and functional limitations coexist.

Considering quality of life related to painful masticatory organ dysfunctions, it should be noted that it will affect painless chewing of food in a functional or physical aspect. Regarding the psychosocial aspect, attention should be paid to the ability of free conversation with others, a mimic response proper
Psychology of TMJPDS 
Joanna $M$.

Biegańska-Banaś Józef K. Gierowski

Ewa Ferendiuk Małgorzata Pihut Katarzyna Adamczyk to the course of interaction not interrupted by pain, or, on the other hand, unhindered by embarrassment caused by wearing an occlusal splint to relieve the ailments. Moreover, the presence of chronic pain might lead to increased irritability and loss of attentiveness in interpersonal relations, as well as the tendency to avoid contact with other people, resulting from, among others, difficulties in performing the social function of eating. The painful form of masticatory organ dysfunctions determines everyday functioning, negatively affecting the quality of sleep or execution of daily tasks (Resende et al., 2013).

Systematic research dedicated to these issues indicates that pain experienced due to masticatory organ dysfunctions significantly reduces the quality of patients' functioning in the areas such as energy, physical mobility, sleep, emotional reactions, and, finally, pain (Bal \& Celiker, 2009; Dao, Lund, \& Lavigne, 1994). The dynamics of changes in the experiences of pain and progressive changes in other aspects of quality of life seem to be particularly interesting. Longitudinal studies (Alajbeg, Gikić, \& Valentić-Peruzović, 2014) showed that the health-related quality of life of patients with masticatory organ dysfunctions, who suffer from myofascial pain, show regular improvement during stabilisation splint therapy - at least during the six-month period included in the study observations. Reduced intensity of pain together with better ability to open the mouth wider transpired to be an important factor determining improvement in the quality of life. Interestingly, the initial level of pain experienced, measured by the quantitative VAS scale, does not seem, in this context, to be an important factor, and nor were age or duration of dysfunction (Oliveira et al., 2003a, 2003b).

Another longitudinal study, covering a period of six months (Reisine \& Weber, 1989), showed that although the measured level of pain experienced by patients reduced over time, functional aspects, and those associated with oral cavity health, did not undergo substantial improvement. This difference may be due to the relatively slow response of these parameters to the process of treatment, in contrast to the relatively fast response of pain. The same authors also described a relatively low estimation of well-being and high estimation of anxiety, which might indicate the psychological characteristics of this group of patients, as well as the interesting observation that persistent experiences of pain (even if there was a significant reduction of the symptoms) are associated with the lack of improvement in perceived quality of life. At the same time, there were no significant differences in symptoms of social isolation compared to the group of healthy subjects, indicating that these patients do not show problems related to the social sphere. However, other authors argue that social disorders are secondary to the unresolved disorders of a dental nature (Oliveira et al., 2003b).
In view of the above few empirical reports, the purpose of this study was to acquire broader knowledge of the specifics of the health-related quality of life among patients with muscle-related masticatory organ dysfunctions, with particular emphasis on the characteristics of experienced pain. Considerations about pain were extended to include its localisation and quality characteristics, which have not been addressed yet in the available publications dedicated to patients suffering from masticatory organ dysfunctions, and what the authors considered an important complement to the analysed issue. Thus, the study attempted to answer two key research questions:

- Which aspects of everyday function of patients with masticatory organ dysfunctions are the greatest nuisance for most patients?

- How does the image of the health-related quality of life in this group of patients change depending on the duration, localisation, intensity, and nature of pain?

\section{PARTICIPANTS AND PROCEDURE}

\section{THE SUBJECTS}

The study was part of a bigger, long-term research project that took place between June 2014 and June 2016. A total of 65 subjects began the project; however, 39 participants dropped out after the first phase of studies, and the retention rate was $40.00 \%$. The dropout was related to chance events, which are not considered related to the clinical picture. The analysis eventually included the results of 26 patients (18 women and eight men) from the Masticatory System Functional Disorders Laboratory of the Dental Prosthetic Clinic at the Jagiellonian University Medical College. The average age of the subjects was 36 years $(S D=12.00)$, the youngest subject was 20 , and the oldest was 68 years old. The subjects were recruited from patients who sought medical attention due to preauricular region pain and were diagnosed by a specialist in prosthetic dentistry with the painful form of muscle-related functional masticatory organ disorders. All patients were first-time visitors to the clinic with the purpose of diagnosis and complex specialist treatment, in generally good health, with complete dental arches, and without injury history over the preceding two years. Financial compensation for participation in the study was not provided; however, the patients had the opportunity to attend five psychoeducational meetings with a psychologist, aimed at increasing awareness of a psychogenic factor in functional masticatory organ disorders and better coping with stress by learning techniques for reducing the level of perceived psychophysical tension. 


\section{METHODS}

The set of questionnaires consisted of three tools: Questionnaire Regarding Pain Sensations in Masticatory Organ Dysfunctions, Pain Evaluation Sheet, and Oral Health Impact Profile.

Questionnaire Regarding Pain Sensations in Masticatory Organ Dysfunctions is an original, self-descriptive tool consisting of nine questions, directed at obtaining basic socio-demographic data. Information regarding the frequency, dynamics, and intensity of pain, and taking into account decreasing and increasing pain, and the use of painkillers as well as the localisation of the experiences of pain.

Pain Evaluation Sheet modified by Szatanik (1985) allows the measurement of pain intensity based on the words chosen by the subject, which the most accurately describe their feelings at the moment. Additionally, it provides a qualitative measurement of the experiences of pain, taking into account sensory and emotional aspects. The tool consists of 43 words divided into 20 groups, taking into account two categories: items 1-15 are the sensory category, and items 16-20 are the emotional category.

Oral Health Impact Profile is a self-descriptive tool aiming to determine dysfunctions, discomfort, and disability attributed to the condition of the oral cavity. The questionnaire consists of 49 questions, of which three concern dentures, and, according to the authors' instructions, they are omitted in the case of patients who do not have this problem. Since most of the subjects who took part in the test procedure did not have dentures, which was also the case in the current study, the questions were omitted in the questionnaire presented to the subjects and, therefore, in the further analyses. The instructions to the questionnaire indicated that the next questions concern only those experiences that result from functional disorders of the masticatory organ. The questionnaire consists of a list of potential consequences of the experienced disorders and their impact on everyday functioning of the subjects in several areas, namely: functional limitations, physical pain, psychological discomfort, physical limitations, psychological limitations, interpersonal limitations, and disability/impairment concerning performance of social roles such as working. The subjects were asked to indicate on a Likert five-degree scale how often they experience particular problems in relation to the period of time indicated in the instructions; in the study it was one month. The possible answers are: 1 - very often/all the time, 2 - quite often, 3 - sometimes, 4 - hardly ever, or 5 - never. The questionnaire is characterised by high internal reliability; Cronbach's coefficient $\alpha$ in the analyses (Locker \& Slade, 1993; Slade \& Spencer, 1994; Slade et al., 1996) amounted to between .70 and .96 for all subscales, but in one study (58) it amounted to .37 for the subscale of disability. In our study, internal reliability was high, ranging between .74 for psychological discomfort and .92 for impairment of social roles.

\section{PROCEDURE}

The patients who, due to masticatory organ dysfunctions, entered the Functional Disorders Clinic for prosthetic treatment were invited by the attending physician to participate in the study preceded by a briefing with a psychologist conducting the test procedure. The main criterion to participate in the study was diagnosis of a painful form of muscle-related functional organ disorders in the clinical picture. The exclusion criteria were the patients' will and general diseases that prevent the planned test procedure.

After obtaining the patient's consent to meeting with a psychologist, which was intended to explain the purpose and procedures of the study, the psychologist asked the patients if they wanted to participate in the study, providing them with sufficiently detailed information about the project.

Subsequently, the subjects were invited to a meeting during which they were asked to fill in paper-pencil questionnaires, as established in the test procedure. The study was conducted individually and was held in the presence of a psychologist. The complete test procedure lasted approximately 20 minutes.

\section{ETHICAL CONSIDERATIONS}

The study protocol was approved by the Bioethical Committee of Jagiellonian University (decision number KBET/172/B/2014). Potential participants received a copy of the consent document to read before the screening visit. At the screening visit, the principle investigator reviewed the informed consent document with the potential participant, who then had the opportunity to ask questions. Each participant was informed that the study was conducted as part of a doctoral thesis in the field of psychology, and its goal was to study the issue of pain in masticatory organ dysfunctions as well as its impact on everyday life. The person informing participants about the study assured them that the study was anonymous and participation was voluntary, he/she also emphasised that the results would not be used in any way by the medical staff. Participation in the study were provided an opportunity to gain free prothetical diagnosis and psychoeducation on stress management. If an eligible patient decided to enrol in the study, the investigator then obtained written consent.
Psychology of TMJPDS 


\section{RESULTS}

\section{DESCRIPTION OF PAIN IN THE GROUP OF SUBJECTS}

The vast majority of people surveyed ( 9 people) at the time of the study experienced pain associated with masticatory organ dysfunctions several times a day, and another three people less frequently, i.e. 1-2 times a day. Among the people surveyed were subjects who

Joanna M. Biegańska-Banaś Józef K. Gierowski Ewa Ferendiuk Małgorzata Pihut Katarzyna Adamczyk experienced pain in a continuous manner, i.e. all the time (three people). Four people experienced pain several times a week, while seven people experienced it several times a month or less frequently.

More than half of the respondents reported that the pain had not changed significantly since the first diagnosis of masticatory organ dysfunctions (15 people). Five of the subjects claimed that the pain increased, while six said that the pain reduced.

At the time of the study, the vast majority of the respondents estimated that the experienced pain was between two and six on the quantitative scale.

The subjects felt the strongest pain between $4 \mathrm{pm}$ and $6 \mathrm{pm}$. It can be also observed that it began to systematically increase at $12 \mathrm{pm}$ and gradually fall until $8 \mathrm{pm}$. Thus, pain was significantly less intense before $12 \mathrm{pm}$ and after $8 \mathrm{pm}$. Relatively few people reported pain in the morning and at night. Thanks to the so-called spaghetti diagram, a precise observation of changes in pain pathways in individual subjects over time is possible. The presented diagram allows the observation that the previously described dynamics of pain in this studied group is relatively homogenous, although it is possible to identify a few people among the subjects who had a different pain

pattern, but these are rather isolated cases. For example, there was a person among the subjects who felt the strongest pain during late evening and maximum pain intensity persisted until late night. A thorough analysis of the patient's medical records suggests that the bone component, in her case, takes a relatively greater part in the overall image of dysfunction in comparison to other subjects.

The factors indicated most frequently by the subjects as pain intensifying were: fatigue (19 responses), deliberate movements of the jaw (18 responses), food intake (18 responses), cough (15 responses), standing position and cold air (14 responses each), and noise (13 responses). The subjects chose significantly fewer pain reducing factors than factors that increase this kind of ailment; few responses included a lying position or caffeinated drinks (11 responses).

As many as 20 of 26 subjects experienced pain on both sides of the head and neck. Most of the subjects indicated the right side (15) and the left side (12) of the temporomandibular joint region, as well as the right side (12) and the left side (11) of the auricular region. Subsequently, the subjects indicated the right side (10) and the left side (9) of the parotideomasseteric region, and the right and the left side (9) of the posterior triangle of the neck.

The factors most intensifying pain were assigned to the infraorbital region; however, they were indicated only by one subject, who claimed that he/ she felt pain in this part of the face. The regions of pain in which experienced pain was intensified by a significant number of factors and which were indicated by a minimum of $35.00 \%$ of the subjects were: the left and the right side of the posterior triangle of the neck, the right side of the parotideomasseteric region, and the left side of temporomandibular joint

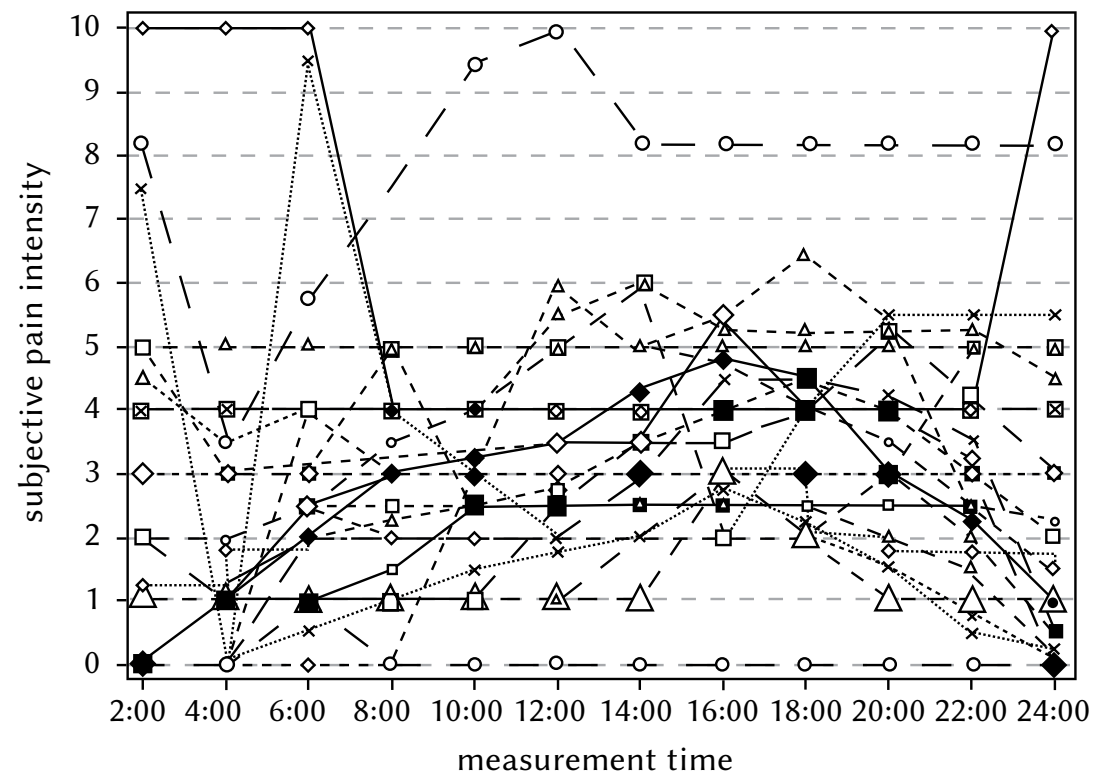

Figure 1. The spaghetti diagram illustrating paths set by the change in pain intensity within 24 hours for all the subjects. 
Table 1

Factors increasing, reducing, or having no impact on the experiences of pain as indicated by the subjects. Colours used in table fields reflect intensity of a given factor in a given category, i.e. from intense green (no impact) to intense orange (strong impact)

\begin{tabular}{|c|c|c|c|}
\hline & reduced pain & no impact & increased pain \\
\hline & number & number & number \\
\hline deliberate movements of the jaw & 4 & 4 & 18 \\
\hline food intake & 2 & 6 & 18 \\
\hline running & 0 & 21 & 5 \\
\hline verticalization & 0 & 21 & 5 \\
\hline hot air & 1 & 20 & 6 \\
\hline warm food/drinks & 1 & 21 & 4 \\
\hline standing position & 2 & 21 & 3 \\
\hline vibrations & 1 & 12 & 14 \\
\hline cold air & 4 & 16 & 7 \\
\hline strong emotions & 0 & 12 & 14 \\
\hline cold food/cold drinks & 4 & 11 & 11 \\
\hline lying position & 6 & 15 & 5 \\
\hline alcohol & 11 & 11 & 4 \\
\hline massage/rubbing & 6 & 11 & 9 \\
\hline fatigue & 5 & 9 & 12 \\
\hline sudden movements & 1 & 6 & 19 \\
\hline sitting position & 3 & 13 & 10 \\
\hline cough & 0 & 14 & 12 \\
\hline noise & 0 & 11 & 15 \\
\hline caffeinated drinks & 0 & 11 & 13 \\
\hline walk & 11 & 14 & 1 \\
\hline physical effort & 4 & 11 & 11 \\
\hline moisture & 4 & 15 & 8 \\
\hline other factors & 3 & 22 & 1 \\
\hline
\end{tabular}

Psychology of TMJPDS region (10 factors intensifying pain), followed by the right side of the temporomandibular joint region, the left and the right side of the auricular region (9 factors intensifying pain), and the left side of the parotideomasseteric region (8 factors intensifying pain).

The subjects indicated significantly fewer factors reducing pain in the specific anatomical regions of the head and neck than factors that increase the experiences of pain. Most responses regarding factors reducing pain, indicated by a minimum of $35.00 \%$ of the subjects, concerned the right and the left side of the posterior triangle of the neck, the left side of the temporomandibular joint, the left side of the auricular region (an average of 4 factors), followed by the right side of the parotideomasseteric region and the right side of the temporomandibular joint region (an average of 3 factors).
Analysis of the average of the medians of estimated intensity of pain experiences showed that the highest values were linked to the infraorbital region $(M=$ 7.33) and the right side of the buccal region $(M=6.33)$ as painful; however, each response was given only by one person. The relatively high averages of the medians of the estimated pain experiences having a higher number of responses were related to the left side of the mastoid region $(M=5.67)$, the right side of the occipital region $(M=5.33)$, the left side $(M=5.17)$ and the right side $(M=5.00)$ of the parotideomasseteric region, the mental region $(M=5.00)$, the left side of the posterior triangle of the neck $(M=4.67)$, and the nuchal region $(M=4.33)$. The highest medians of the recorded values of pain experiences were linked to the right side of the buccal region $(M e=11.00)$ - estimated by one subject 
Table 2

Number of responses indicating the pain regions and the percentage regarding pain localised in different regions of the face and neck (anatomical division after Aleksandrowicz and Ciszek [2013], completed and changed after an oral consultation with a physiotherapist, Piotr Kazana)

\begin{tabular}{|c|c|c|}
\hline region of face & number of subjects & $\%$ subjects \\
\hline nuchal & 4 & 16.00 \\
\hline mental & 3 & 12.00 \\
\hline infraorbital & 1 & 4.00 \\
\hline suboccipital & 5 & 20.00 \\
\hline occipital right & 2 & 8.00 \\
\hline occipital left & 2 & 8.00 \\
\hline posterior triangle of the neck right & 9 & 36.00 \\
\hline posterior triangle of the neck left & 9 & 36.00 \\
\hline mastoid process right & 6 & 24.00 \\
\hline mastoid process left & 7 & 28.00 \\
\hline parietal right & 1 & 4.00 \\
\hline parietal left & 1 & 4.00 \\
\hline frontal central & 4 & 16.00 \\
\hline frontal right & 2 & 8.00 \\
\hline frontal left & 2 & 8.00 \\
\hline temporal right & 8 & 32.00 \\
\hline temporal left & 3 & 12.00 \\
\hline parotideomasseteric right & 10 & 40.00 \\
\hline parotideomasseteric left & 9 & 36.00 \\
\hline buccal right & 1 & 4.00 \\
\hline buccal left & 0 & 0.00 \\
\hline zygomatic right & 5 & 20.00 \\
\hline zygomatic left & 5 & 20.00 \\
\hline temporomandibular joint right & 15 & 60.00 \\
\hline temporomandibular joint left & 12 & 48.00 \\
\hline inferior mandibular ramus right & 7 & 28.00 \\
\hline inferior mandibular ramus left & 7 & 28.00 \\
\hline auricular right & 12 & 48.00 \\
\hline auricular left & 11 & 44.00 \\
\hline nasal & 2 & 8.00 \\
\hline symptoms on both sides & 20 & 80.00 \\
\hline
\end{tabular}

- the right and the left side of the parietal region $(M e=$ $10.00)$, the left side of the zygomatic region $(M e=10.00)$, the nuchal region $(M e=10.00)$, the left side of the mastoid region $(M e=9.00)$, the left and the right side of the parotideomasseteric region $(M e=9.00)$, and the right side of the auricular region $(M e=9.00)$.

Analysing the medians of the frequency of the pain experienced, it can be noted that there is a clear distinction between the regions in which the subjects observed the presence of pain several times a day, and the ones in which pain occurred less frequently - several times a week. The first group includes the right and the left side of the temporomandibular joint region, both sides of the auricular region, the right side of the temporal region, both sides of the mastoid region, both sides of the inferior mandibular 
Table 3

Number of responses indicating the pain regions and the percentage regarding pain localised in different regions of the face and neck (anatomical division after Aleksandrowicz and Ciszek [2013], completed and changed after an oral consultation with a physiotherapist, Piotr Kazana)

\begin{tabular}{|c|c|c|}
\hline region of face & number of subjects & $\%$ subjects \\
\hline nuchal & 4 & 16.00 \\
\hline mental & 3 & 12.00 \\
\hline infraorbital & 1 & 4.00 \\
\hline suboccipital & 5 & 20.00 \\
\hline occipital right & 2 & 8.00 \\
\hline occipital left & 2 & 8.00 \\
\hline posterior triangle of the neck right & 9 & 36.00 \\
\hline posterior triangle of the neck left & 9 & 36.00 \\
\hline mastoid process right & 6 & 24.00 \\
\hline mastoid process left & 7 & 28.00 \\
\hline parietal right & 1 & 4.00 \\
\hline parietal left & 1 & 4.00 \\
\hline frontal central & 4 & 16.00 \\
\hline frontal right & 2 & 8.00 \\
\hline frontal left & 2 & 8.00 \\
\hline temporal right & 8 & 32.00 \\
\hline temporal left & 3 & 12.00 \\
\hline parotideomasseteric right & 10 & 40.00 \\
\hline parotideomasseteric left & 9 & 36.00 \\
\hline buccal right & 1 & 4.00 \\
\hline buccal left & 0 & 0.00 \\
\hline zygomatic right & 5 & 20.00 \\
\hline zygomatic left & 5 & 20.00 \\
\hline temporomandibular joint right & 15 & 60.00 \\
\hline temporomandibular joint left & 12 & 48.00 \\
\hline inferior mandibular ramus right & 7 & 28.00 \\
\hline inferior mandibular ramus left & 7 & 28.00 \\
\hline auricular right & 12 & 48.00 \\
\hline auricular left & 11 & 44.00 \\
\hline nasal & 2 & 8.00 \\
\hline symptoms on both sides & 20 & 80.00 \\
\hline
\end{tabular}

ramus, and the suboccipital region. The second group consists of both sides of the posterior triangle of the neck, both sides of the parotideomasseteric region, and both sides of the zygomatic region.

Analysing the pain reported by the subjects in terms of quality, the estimated intensity of sensory and emotional pain was converted so that it could reach the minimum theoretical value $(0)$ and the maximum theoretical value (1). In order to do this, the raw score was divided by the maximum value of the given scale (i.e. 170 for sensory pain [34 questions $\times 5$ points] and 55 for emotional pain [11 questions $\times 5$ points]). Therefore, the obtained values are presented as a percentage of the maximum score. The estimates regarding emotional pain and the ones regarding sensory pain were attributed, to a large extent, to the same values, although in the case of emotional pain slightly higher estimates appeared as well. Moreover, a Spearman's @ correlation analysis showed that, on average, greater emo-
Psychology of TMJPDS 
Table 4

Number of responses indicating factors increasing and reducing pain

Joanna $M$.

Biegańska-Banaś Józef K. Gierowski

Ewa Ferendiuk Małgorzata Pihut

Katarzyna Adamczyk

\begin{tabular}{|c|c|c|}
\hline \multicolumn{3}{|c|}{ Factors increasing pain } \\
\hline anatomical area of the head/neek & number & $\begin{array}{l}\text { average number of factors } \\
\text { increasing pain }\end{array}$ \\
\hline buccal left & 0 & - \\
\hline infraorbital & 1 & 11.00 \\
\hline posterior triangle of the neck left & 9 & 10.67 \\
\hline mental & 3 & 10.33 \\
\hline parotideomasseteric right & 10 & 10.00 \\
\hline suboccipital & 5 & 10.00 \\
\hline buccal right & 1 & 10.00 \\
\hline posterior triangle of the neck right & 9 & 9.89 \\
\hline temporomandibular joint left & 25 & 9.73 \\
\hline temporal left & 3 & 9.67 \\
\hline zygomatic right & 5 & 9.60 \\
\hline temporomandibular joint right & 12 & 9.25 \\
\hline auricular left & 11 & 9.09 \\
\hline mastoid process left & 7 & 9.00 \\
\hline auricular right & 12 & 8.67 \\
\hline parotideomasseteric left & 9 & 8.44 \\
\hline zygomatic left & 5 & 8.40 \\
\hline mastoid right & 6 & 7.67 \\
\hline nuchal & 4 & 7.25 \\
\hline occipital right & 2 & 7.00 \\
\hline frontal & 4 & 6.75 \\
\hline frontal right & 2 & 6.50 \\
\hline frontal left & 2 & 6.50 \\
\hline nasal & 2 & 6.50 \\
\hline inferior mandibular ramus right & 7 & 6.29 \\
\hline inferior mandibular ramus left & 7 & 6.29 \\
\hline parietal right & 1 & 6.00 \\
\hline parietal left & 1 & 6.00 \\
\hline temporal right & 8 & 5.88 \\
\hline occipital left & 2 & 4.50 \\
\hline
\end{tabular}

(Table 4 continues)

tional pain reported by a subject correlated with greater sensory pain: $\varrho=.63, p<.001$.

\section{PAIN AND QUALITY OF LIFE}

To verify the statistical significance of correlation between variables: frequency of pain and quality of life, a series of Pearson's r correlations was performed, but it did not show any statistically significant differences.
However, it showed a weak tendency indicating that the longer the periods of time without pain the subjects experienced, the higher their average estimates of quality of life: $\varrho(24)=.41, p<.05$ (Fig. 2). Covariance proved to be statistically significant only for quality of life seen as a whole; there were no statistically significant covariances for the remaining categories of quality of life.

To find out whether the intensity of the strongest and the weakest pain experienced by the subjects at 


\begin{tabular}{|c|c|c|}
\hline anatomical area of the head/neck & number & $\begin{array}{l}\text { average number of factors } \\
\text { increasing pain }\end{array}$ \\
\hline buccal left & 0 & - \\
\hline temporal left & 3 & 5.00 \\
\hline buccal right & 1 & 5.00 \\
\hline posterior triangle of the neck left & 9 & 4.44 \\
\hline posterior triangle of the neck right & 9 & 3.89 \\
\hline suboccipital & 5 & 3.80 \\
\hline zygomatic right & 5 & 3.80 \\
\hline temporomandibular joint left & 15 & 3.73 \\
\hline auricular left & 11 & 3.64 \\
\hline mental & 3 & 3.33 \\
\hline parotideomasseteric right & 10 & 3.10 \\
\hline infraorbital & 1 & 3.00 \\
\hline mastoid process left & 7 & 3.00 \\
\hline parietal right & 1 & 3.00 \\
\hline parietal left & 1 & 3.00 \\
\hline zygomatic left & 5 & 3.00 \\
\hline mastoid process right & 6 & 2.83 \\
\hline temporomandibular joint right & 12 & 2.67 \\
\hline temporal right & 8 & 2.38 \\
\hline parotideomasseteric left & 9 & 2.22 \\
\hline auricular right & 12 & 2.17 \\
\hline inferior mandibular ramus left & 7 & 2.14 \\
\hline inferior mandibular ramus right & 7 & 2.14 \\
\hline occipital right & 2 & 1.50 \\
\hline frontal & 4 & 1.50 \\
\hline nuchal & 4 & 1.00 \\
\hline occipital left & 2 & 1.00 \\
\hline nasal & 2 & 1.00 \\
\hline frontal right & 2 & 0.50 \\
\hline frontal left & 2 & 0.50 \\
\hline
\end{tabular}

the time of the study showed any covariance with the scores on the quality of life scales, further correlation analyses were performed. The obtained results, showing statistically significant negative correlation between the estimates of the strongest experiences of pain and quality of life, suggested that the higher the estimates of the strongest pain related to the masticatory organ dysfunctions, the lower the overall quali- ty of life of the subjects: $\varrho(24)=-.40, p<.05$. The obtained results also showed a statistically significant negative correlation between the strongest pain and physical pain domain of quality of life: $\varrho(24)=-0.52$, $p<.010$, and the strongest pain and psychological discomfort domain of quality of life: $\varrho(24)=-.51$, $p<.010$. Thus, the higher the estimates of the strongest pain felt by the subjects, the lower the quality of
Psychology of TMJPDS 
Table 5

Frequency of the experiences of pain localised in different regions

Joanna M. Biegańska-Banaś Józef K. Gierowski Ewa Ferendiuk Małgorzata Pihut Katarzyna Adamczyk

\begin{tabular}{|c|c|}
\hline anatomical region of head/neck & $\begin{array}{c}\text { frequency } \\
\text { number }\end{array}$ \\
\hline buccal right & 1 \\
\hline posterior triangle of the neck right & 9 \\
\hline posterior triangle of the neck left & 9 \\
\hline parotideomasseteric left & 9 \\
\hline zygomatic right & 5 \\
\hline zygomatic left & 5 \\
\hline nuchal & 4 \\
\hline mental & 3 \\
\hline temporal left & 3 \\
\hline occipital left & 2 \\
\hline occipital right & 2 \\
\hline parietal right & 1 \\
\hline parietal left & 1 \\
\hline parotideomasseteric right & 10 \\
\hline temporomandibular joint left & 15 \\
\hline temporomandibular joint right & 12 \\
\hline auricular right & 12 \\
\hline auricular left & 11 \\
\hline temporal right & 8 \\
\hline mastoid process left & 7 \\
\hline inferior mandibular ramus right & 7 \\
\hline inferior mandibular ramus left & 7 \\
\hline mastoid process right & 6 \\
\hline suboccipital & 5 \\
\hline infraorbital & 1 \\
\hline frontal central & 4 \\
\hline frontal right & 2 \\
\hline frontal left & 2 \\
\hline nasal & 2 \\
\hline buccal left & 0 \\
\hline
\end{tabular}

life related to the experienced physical pain and the lower psychological comfort felt by the subject. The weakest pain felt by the subjects negatively correlated only with quality of life social dysfunctions: @ (24) $=-.47, p<.05$. This result shows that the lower the estimates of the weakest pain related to masticatory organ dysfunctions, the higher the quality of life related to social functioning. There were no statistical-

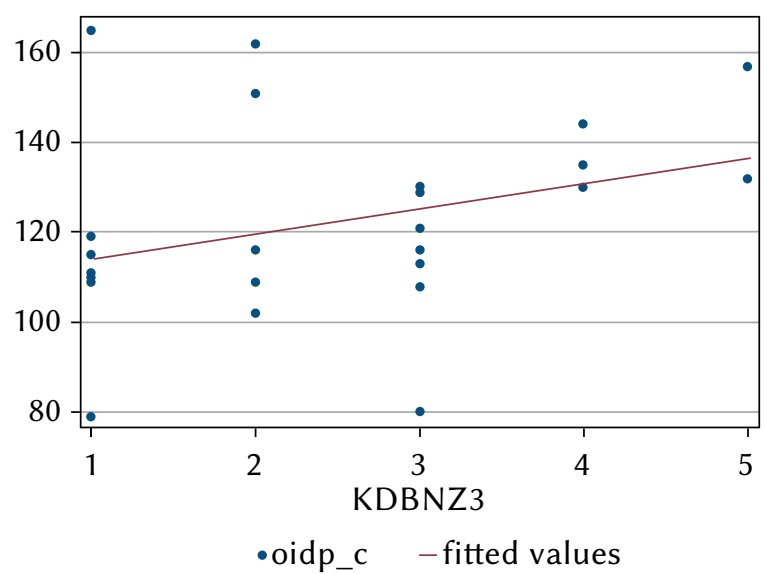

Figure 2. The length of period of time without pain and the estimated quality of life: $\varrho(24)=.41, p<.05$.

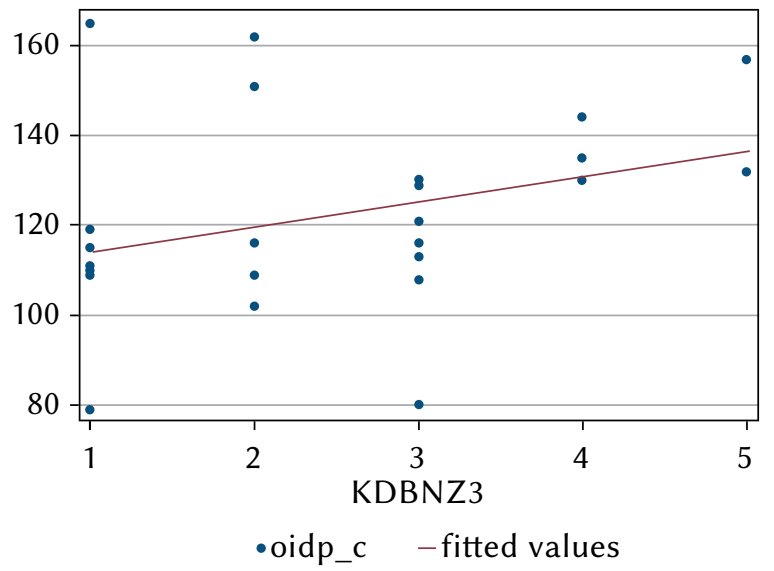

Figure 3. Number of indications localising the experiences of pain and quality of life: $\varrho(24)=-.38, p=.050$.

ly significant covariances between the estimates of currently experienced pain and quality of life.

The expected covariance of quality of life and the number of factors that intensify or reduce pain experienced due to masticatory organ dysfunctions was confirmed by performing further Spearman's rho correlation analyses. Statistically significant but negative effects for factors reducing pain and quality of life as a whole were obtained: $\varrho(24)=-.44, p<.05$, and factors reducing pain and quality of life physical dysfunctions: $\varrho=-.50, p<.01$. At the same time, the analyses showed statistically significant negative correlations between the number of factors intensifying the experiences of pain and quality of life as a whole: $\varrho=-.46, p<.05$, quality of life functional limitations: $\varrho(24)=-.41, p<.05$, quality of life physical pain: $\mathrm{Q}=-.43, p<.05$, quality of life physical dysfunctions: $\varrho(24)=-.45, p<.05$, and quality of life psychological dysfunctions: $\varrho(24)=-.40$, $p<.05$. Thus, the results of the analyses lead to the conclusion that the more pain intensifying factors in 
the masticatory organ dysfunctions, the lower the overall quality of life and quality of life related to the experienced physical pain, physical functioning, and psychological functioning.

To determine whether quality of life showed covariance for both the sensory category of pain and the emotional category of pain, further correlation analyses were performed. They showed statistically significant effects only for the emotional category of pain. There was a negative correlation between quality of life as a whole and the emotional category of pain: $\varrho(24)=-.47, p=.01$. Therefore, the higher the emotional category of pain, the lower the overall quality of life of the subjects. Other statistically significant correlation analyses were related to quality of life physical dysfunctions: $\varrho(24)=-.47$, $p=.015$, and quality of life psychological dysfunctions: $\varrho(24)=-.44, p<.05$. These results indicate that the stronger the experienced emotional pain, the lower the quality of life viewed in terms of physical and psychological functionality.

Correlation analysis confirmed that the greater the number of localisations of pain indicated by the subjects, the lower the perceived quality of life: $\varrho(24)$ $=-.38, p=.055$.

Observation of the average estimates of quality of life showed that people who experienced pain localised in the right and the left side of the frontal region, both sides of the zygomatic region, the mental region, the parotideomasseteric region, and the right side of the occipital region had the lowest level of quality of life. People having the highest quality of life had localised pain in the buccal region, the right side of the temporal region, the central part of the frontal region, the left side of the parotideomasseteric region, and the right side of the posterior triangle of the neck.

\section{DISCUSSION}

The pain characteristic of the clinical group of patients suffering from masticatory organ functional disorders was described by the subjects as chronic, experienced several times a day. At the time of the study, most of the subjects reported persistent pain. This is consistent with the fact that all the subjects entered the clinic following an often long diagnostic process that was frequently preceded by previous therapeutic failures, and the study was directly preceded by the therapeutic process. Pain intensity estimated by the patients is consistent with previous reports, indicating moderate estimates of pain on the quantitative scales. However, contrary to previous reports, which indicated that pain was persistent in the evening, the studied group felt the most intense pain in the late afternoon. This interesting difference deserves intercultural considerations. The hours
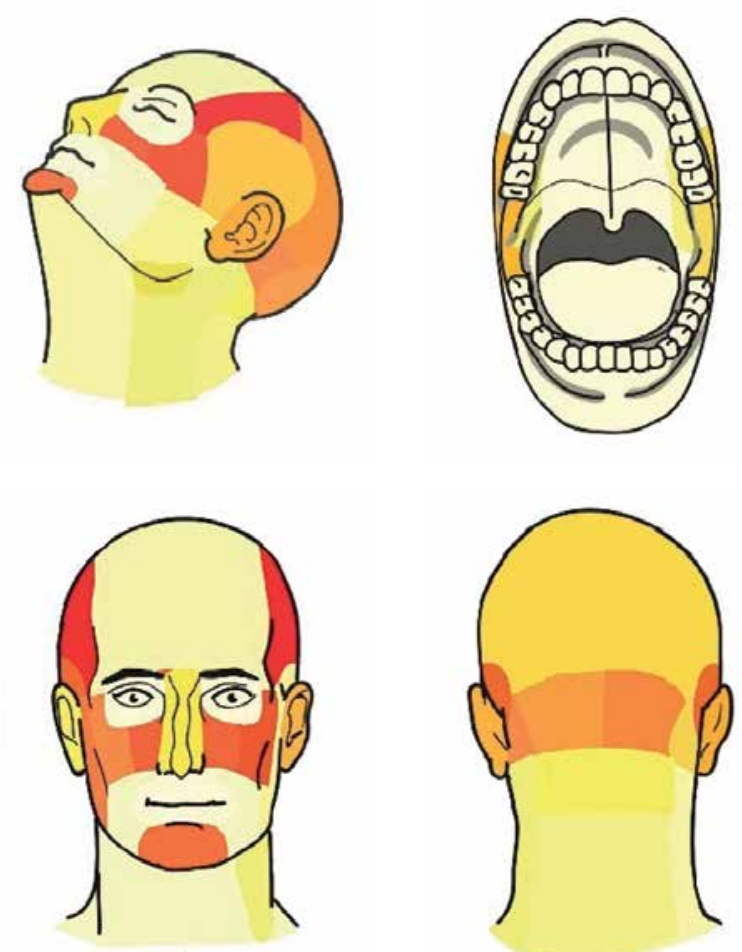

Psychology of TMJPDS
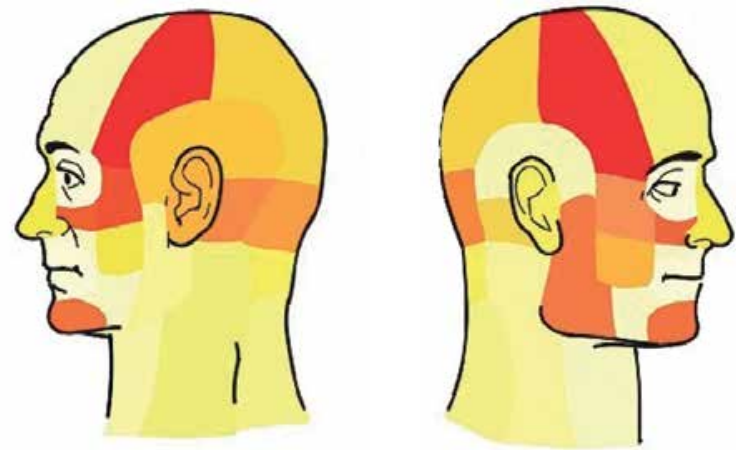

Figure 4. Face and mouth profiles illustrating correlations between different pain areas and quality of life. Less intense colours indicate worse quality of life.

during which pain was the strongest, in the case of people working in Poland, were the hours at the end of the day shift. Pain seems to be correlated with a possible progressing physical and mental fatigue associated with fulfilling professional duties. Consistency of this interpretation can be emphasised by the fact that symptoms were reported to gradually buildup from the beginning of the day. This mechanism can be explained by a significant accumulation of the factors that intensify pain in a work environment. Taking into account only those listed in the study by the subjects, which might be associated with a work environment, the following can be listed: strong emotions, progressing physical fatigue, increased coffee consumption, physical effort, and/or sitting 
Table 6

The average estimates of quality of life among groups of patients experiencing different frequencies of pain experiences in the given regions of the face and neck

Biegańska-Banaś Józef K. Gierowski Ewa Ferendiuk Małgorzata Pihut Katarzyna Adamczyk

\begin{tabular}{|c|c|c|c|c|c|c|}
\hline $\begin{array}{l}\text { anatomical region of } \\
\text { head/neck }\end{array}$ & number & average & $\begin{array}{l}\text { the standard } \\
\text { error of the } \\
\text { average }\end{array}$ & median & $\max$ & $\min$ \\
\hline buccal left & 0 & - & - & - & - & - \\
\hline buccal right & 1 & 130.00 & - & 130.00 & 130 & 130 \\
\hline temporal right & 8 & 126.38 & 7.60 & 115.50 & 162 & 109 \\
\hline frontal central & 4 & 126.25 & 12.17 & 117.00 & 162 & 109 \\
\hline parotideomasseteric left & 9 & 124.44 & 8.53 & 130.00 & 165 & 80 \\
\hline $\begin{array}{l}\text { posterior triangle of the neck } \\
\text { right }\end{array}$ & 9 & 123.67 & 5.25 & 116.00 & 157 & 109 \\
\hline nuchal & 4 & 122.25 & 18.14 & 122.00 & 165 & 80 \\
\hline $\begin{array}{l}\text { inferior mandibular ramus } \\
\text { right }\end{array}$ & 7 & 120.86 & 10.94 & 113.00 & 162 & 80 \\
\hline inferior mandibular ramus left & 7 & 120.86 & 10.94 & 113.00 & 162 & 80 \\
\hline $\begin{array}{l}\text { posterior triangle of the neck } \\
\text { left }\end{array}$ & 9 & 118.00 & 3.51 & 116.00 & 135 & 108 \\
\hline suboccipital & 5 & 117.80 & 14.12 & 110.00 & 162 & 80 \\
\hline auricular right & 12 & 117.00 & 7.36 & 112.00 & 165 & 79 \\
\hline nasal & 2 & 117.00 & 4.00 & 117.00 & 121 & 113 \\
\hline $\begin{array}{l}\text { temporomandibular } \\
\text { joint left }\end{array}$ & 15 & 116.73 & 5.48 & 113.00 & 157 & 79 \\
\hline mastoid process right & 6 & 116.33 & 10.80 & 109.00 & 157 & 80 \\
\hline parietal right & 1 & 116.00 & - & 116.00 & 116 & 116 \\
\hline parietal left & 1 & 116.00 & - & 116.00 & 116 & 116 \\
\hline temporal left & 3 & 116.00 & 8.08 & 116.00 & 130 & 102 \\
\hline $\begin{array}{l}\text { temporomandibular joint_- } \\
\text { right }\end{array}$ & 12 & 115.67 & 6.56 & 112.00 & 157 & 79 \\
\hline auricular left & 11 & 114.64 & 7.12 & 113.00 & 165 & 79 \\
\hline occipital left & 2 & 114.00 & 1.00 & 114.00 & 115 & 113 \\
\hline mastoid process left & 7 & 113.29 & 7.67 & 109.00 & 144 & 80 \\
\hline zygomatic right & 5 & 113.20 & 1.24 & 113.00 & 116 & 110 \\
\hline occipital right & 2 & 113.00 & 2.00 & 113.00 & 115 & 111 \\
\hline parotideomasseteric right & 10 & 111.70 & 7.67 & 109.50 & 165 & 79 \\
\hline mental & 3 & 111.33 & 1.85 & 110.00 & 115 & 109 \\
\hline Infraorbital & 1 & 111.00 & - & 111.00 & 111 & 111 \\
\hline zygomatic left & 5 & 107.40 & 6.94 & 115.00 & 116 & 80 \\
\hline frontal right & 2 & 100.50 & 20.50 & 100.50 & 121 & 80 \\
\hline frontal left & 2 & 100.50 & 20.50 & 100.50 & 121 & 80 \\
\hline
\end{tabular}


position. Review of the literature regarding the issue of stress provides an alternative explanation for this mechanism, indicating that physiological and emotional consequences of stress might be long-term and persistent despite the cessation of the stressor's impact. This, in turn, is consistent with numerous previous empirical reports, which indicated a role for the emotional factor in masticatory organ dysfunctions (Alves, Alchieri, \& Barbosa, 2013; Buljan, 2009; Fillingim et al., 2013; Glaros, Williams, \& Lauste, 2005; Makowiec-Dąbrowska et al., 2009; Pihut, Gierowski, Cerankiewicz, \& Ferendiuk, 2015; Rugh, Woods, \& Dahlstrom, 1993).

It should be noted that among the factors intensifying pain, as indicated by the subjects, were both physical factors, directly or indirectly influencing the stomatognathic system, and psycho-emotional factors, confirming that the experience of pain is multifactorial and multifaceted (Łazowski, 1989; Styczyński, 2001). The subjects indicated significantly fewer factors reducing pain than factors intensifying pain. This information allows indirect inference that people feel considerably helpless in the face of the experienced pain. Aside from the possibility that, in fact, more factors intensify pain experiences in masticatory organ dysfunctions than reduce them, it is important to emphasise the need to educate patients about things as basic as countermeasures against pain. The fact that all the subjects were taking significant quantities of painkillers suggests that, to a large extent, pharmacological agents are a remedy for pain for the subjects. This seems particularly dangerous because studies show the danger of addiction to painkillers in this group of patients (Baron, 2004). Finally, non-medical explanations of the results indicate that greater easiness in generating the factors increasing pain for the subjects can be traced back to the anchoring heuristic (Kahneman et al., 1982). When giving their opinions, people tend to relate to a reference point, in this case pain, which was multidimensionally described in the previous part of the study by the subjects. As a result, contexts with pain were cognitively more available than contexts without it. The analysis of the regions for which subjects generated the largest number of factors intensifying the experiences of pain is worth consideration. These are: the posterior triangle of the neck, parotideomasseteric, temporomandibular joint, and auricular regions. These indications overlap, to a large extent, with the indications of the regions chosen most often as pain regions. This, in turn, is part of the pathomechanism of masticatory organ dysfunctions with the analysed component, including the possibility of pain radiation to the relevant regions (Travell \& Simons, 1983). On the other hand, these indications reflect the attentiveness of the patients and their significant awareness of their own symptoms and their mechanisms. Therefore, it can be inferred that the patients from the studied clinical group have a fairly good knowledge concerning the contribution of different factors in the development and intensification of the experienced pain, which in turn might result from the chronic nature of the pain. Interestingly, at the same time, the subjects had a considerable difficulty indicating factors reducing pain experiences in the same anatomical regions, which might reflect a sense of relatively little influence or, in other words, indicate a conviction of other-directedness in the pain region. Numerous studies dedicated to this issue clearly show that this situation can foster an attitude of resignation and hinder the patient's involvement in the therapeutic process (Kwan, Dimidjian, \& Rivzi, 2010; Omeje \& Chinenye, 2011; Richter \& Hebgen, 2010).

In the course of muscle-related masticatory organ dysfunctions, the regions indicated as the most painful were located in one of the most innervated (via the trigeminal nerve) structures of the body, i.e. the facial area - mainly its central part downwards including the infraorbital, buccal, and mental regions, as well as the parotideomasseteric region towards the back of the head, i.e. the mastoid process, occipital region, the posterior triangle of the neck, and nuchal regions. It should be noted that these regions, to a large extent, do not coincide with the regions indicated most frequently as pain regions in the studied group of patients. Possibly, less frequent ailments in these pain regions make them more painful and chronic pain significantly reduces subjective perception of the intensity of pain through an expression of habitual underestimation of pain stimuli (Cohen et al., 1996; Naliboff \& Cohen, 1989; Peters et al., 1992). The regions indicated as the most painful might additionally suggest that pain, at least in some regions, results from the effect of the so-called trigger points in structures not located in the face, e.g. trapezius muscle, which can result in pain in the posterior triangle of the neck, infraorbital, and mastoid process regions. The regions indicated by the subjects as the ones with particularly increased frequency of pain (several times a day) are the following: the temporomandibular joint, the auricular, temporal, and mastoid process regions, followed by the inferior mandibular ramus region, and both sides of the suboccipital region. Perhaps, it is the frequency of the experienced pain that makes these regions less painful, as shown in previous reports indicating that chronic pain reduces the subjectively perceived intensity of pain. Due to their location, it cannot be ruled out that at least some of the experiences of pain may be caused by trigger points located in other problematic muscle areas - e.g., the trapezius muscle, which might cause pain in the infraorbital region or in the lower neck area.

An interesting observation was made, indicating that longer periods of time without pain can lower
Psychology of TMJPDS 
Joanna $M$. Biegańska-Banaś Józef K. Gierowski Ewa Ferendiuk Małgorzata Pihut Katarzyna Adamczyk awareness of factors influencing pain experiences as well as lower levels of maximum and minimum pain, causing higher subjectively perceived quality of life in the patients (although not all the effects relate to the same areas of quality of life). These results seem to show the significance of two important factors determining a better health-related quality of life, i.e. 1) the presence of periods of time during which a patient is able to function relatively freely, unhindered by pain, and 2) the importance of psychological factors, in the form of previous patterns of pain experiences, and focus on the current somatic state (limiting freedom of behaviour by the sole need to perform or refrain from certain actions) for the experienced quality of life related to health dysfunctions. Interestingly, for a higher quality of life related to the patient as an individual, it was important that the maximum level of the experienced pain was as low as possible, whereas a higher quality of life related to the social aspect was associated with the lowest minimum pain experienced by the patient. This finding reflects the well-accepted idea that the experience of pain may respond to cultural rules and expectations (Lautenbacher \& Fillingim, 2004; Melzack \& Casey, 1962). Another study result, showing that more experiences of pain described in terms of emotional categories had lower estimates of quality of life, could be consistent with the knowledge that comes from research in cognitive psychology indicating the modifying influence of emotional pain on the perception of quality of life (Capraro et al., 2012). Chronicisation of pain suggests that pain experienced by patients is, generally, less intense than in the case of acute pain; however, when pain is chronic, anxiety or fear can transform into frustration, while sadness and low mood can transform into depression. It is important that this relationship refers to both spheres of physical and psychological functioning of patients. The greater the number of locations of the experiences of pain indicated by the subject, the lower the overall quality of life.

The relationship between the health-related quality of life and certain structures of the head and face require further research on a larger group. The obtained results allow for a modest assumption that lower quality of life relates more to facial regions located in the upper part of the face, i.e. the part where there is no muscle tissue (the frontal region and the temporal region). Further inference aimed to determine which factor is more important in this case: a physiological one (related to different sensations linked to different experiences of pain in these structures) or a psychological one (related to experiencing pain in the area associated with the efficiency of cognitive functions), which would make a valuable addition to the presented research.

\section{LIMITATIONS OF THE STUDY}

This study has several important limitations that must be taken into account when interpreting its findings. The key limitations include study design (non-controlled observational study) and the small sample size. The small sample size may have, for example, resulted in insufficient power to detect health-related quality-of-life predictors. It arose mainly from the difficulties in diagnosing pure, or at least clearly dominant, myalgic masticatory system dysfunction variants. Further difficulty was to maintain the sample because it covered people from different regions of the country, often distant from the place of study. This made it extremely hard to contact the people at the very same period of time from the beginning until the second measurement. For this reason, the results should be regarded as preliminary studies and need to be confirmed on a bigger sample. We would like to point out, however, that the effects not yet well described in the scientific lecture and stretched over time, such as quality of life among patients with myofascial pain syndrome related to functional masticatory organ disorders, are often reported as case studies. Therefore, although the dropout rate was noticeable, in light of the still unknown dynamic of quality of life among patients with myofascial pain syndrome in muscle-related functional masticatory organ disorders, it seemed accurate to make some comparisons that are not only qualitative. As the results show, thorough qualitative analysis, independent of replicating the effects on a bigger sample in order to establish the initial pain profile, should be the next step. It would be particularly interesting to expand the quantitative investigation by analysing semi-structured interviews with research participants. Linguistic analysis of narrative and textual pain experience descriptions should be very useful in gathering some more accurate pain specificity information, including its intensity typology and characterisation (Kałwak, 2011). Difficulty showing up for all the data collected leads to reflection that if the informed consent to participate in the research was obtained twice - before first phase of the study and then after the retest phase - it would allow analysis of the whole input material. Yet another weakness of the study is that the general quality of life input was not analysed with the psychoemotional state, because some effects might not be so specific for myofascial pain syndrome experience but rather for other conditions related to muscle-related function of masticatory organ disorders. All the same, it is also possible that the group of patients who eventually participated in the whole project are somehow specific. The fact that all of them participated in a psychoeducation programme is, certainly, not without significance. 


\section{CONCLUSIONS}

The study enabled the description of the experiences of pain and quality of life displayed in a group of patients suffering from the muscle-related masticatory organ dysfunctions. The obtained results confirmed that patients with masticatory organ dysfunctions are more likely to have a lower sense of health-related quality of life. A higher health-related quality of life in the studied group was observed in those patients who: experienced longer periods of time without pain; did not recall any experience of particularly intense pain in the past; experienced pain that was limited to fewer structures of the face and head; generated a small number of factors influencing the experiences of pain (both intensifying and reducing); less intensively described pain using the emotional categories; and experienced pain localised in the buccal region, the right side of the temporal region, the central part of the frontal region, the left side of the parotideomasseteric region, and the right side of the posterior triangle of the neck. Further research should include a larger number of subjects to confirm the observed effects and greater diversity in the various areas of quality of life. The obtained information allows formulation of diagnostic and therapeutic recommendations. It seems that the focus on the above-mentioned effects (such as increasing periods of time without pain, limiting the range of pain, education, and therapeutic actions), aimed at reframing negative memory patterns regarding previous experiences of pain, should constitute one of the first and crucial challenges of personnel working with patients who are diagnosed with muscle-related masticatory organ dysfunctions.

\section{ACKNOWLEDGMENTS}

The authors would like to thank Mrs. Ewa Jańczak-Biegańska for her support in conducting the research, Mrs. Dorota Ortenburger for the gift of her inspirational book, Mr. Krzysztof Kasparek for methodological and statistical guidance, and Mr. Piotr Kazana for useful discussions and professional consultations in the field of physiotherapy.

\section{REFERENCES}

Alajbeg, I. Z., Gikić, M., \& Valentić-Peruzović, M. (2014). Changes in pain intensity and oral health related quality of life in patients with temporomandibular disorders during stabilization splint therapy - a pilot study. Acta Clinica Croatia, 53, 7-16.

Alves, A. C., Alchieri, J. C., \& Barbosa, G. A. S. (2013). Bruxism. Maticatory implications and anxiety. Acta Odontologica Latinoamericana, 26, 15-22.
Asch, S. E. (1946). Forming impressions of personality. Journal of Abnormal and Social Psychology, 41, 258-290.

Bal, S., \& Celiker, R. (2009). Health-Related Quality of Life in Patients with Myofascial Pain Syndrome: A Controlled Clinical Study. Journal of Musculoskeletal Pain, 17, 173-177.

Baron, S. (2004). Wpływ zaburzeń zwarcia ekscentrycznego na wybrane elementy układu stomatognatycznego. Magazyn Stomatologiczny, 5, 62-66.

Buljan, D. (2009). Psychological and psychiatric factors of chronic pain. Medical Science, 501, 129-140.

Canadian Dental Association (2001). Oral health complications. What is oral health? (Approved by Resolution 2001.02, Canadian Dental Association Board of Governors, March 2001). Retrieved from: http://www.cda-adc.ca/en/oral_health/complications/index.asp

Capraro, M., Dalla Valle, M., Podswiadek, M., De Sandre, P., Sgnaolin, E., \& Ferrari, R. (2012). The role of illness perception and emotions on quality of life in fibromyalgia compared with other chronic pain conditions. Reumatismo, 64, 142-150.

Cohen, M. J., Song, Z. K., Schandler, S. L., Ho, W. H., \& Vulpe, M. (1996). Sensory detection and pain thresholds in spinal cord injury patients with and without dysesthetic pain, and in chronic low back pain patients. Somatosensory \& Motor Research, 13, 29-37.

Dao, T. P., Lund, I. P., \& Lavigne, I. P. (1994). Comparison of pain and quality of life in bruxers and patients with myofascial pain of the masticatory muscles. Journal of Orofacial Pain, 8, 350-356.

Dolan, T. A. (2013). Professional education to meet the oral health needs of older adults and persons with disabilities. Special Care in Dentistry, 33, 190-197.

Dworkin, S. F., \& LeResche, L. (1993). Temporomandibular disorder pain: epidemiologic data. APS Bulletin, 3, 12-13.

Dworkin, R. H., \& Massoth, D. (1994). Temporomandibular disorders and chronic pain: disease or illness. Journal of Prosthetic Dentistry, 72, 29-38.

Eliasz, A. (2004). Transakcyjny model temperamentu: analiza właściwości temperamentu z perspektywy nomotetycznego i idiograficznego badania osobowości. In: Z. Chlewiński \& A. Sękowski (Eds.), Psychologia w perspektywie XXI wieku (pp. 49-95). Lublin: Towarzystwo Naukowe KUL.

Engel, G. (1959). Psychogenic pain and the pain prone patient. American Journal of Medicine, 76, 899-918.

Fillingim, R. B., Ohrbach, R., Greenspan, J. D., Knott, C., Diatchenko, L., Dubner, R., ...Maixner, W. (2013). Psychological factors associated with development of TMD: The OPERA perspective cohort study. The Journal of Pain, 14, T75-T90.

Flor, H., \& Turk, D. C. (2006). Cognitive and learning aspects. In: S. B. McMahon \& M. Koltzenburg
Psychology of TMJPDS 
(Eds.), Wall and Melzack handbook of pain (pp. 241-258). Philadelphia: Elsevier.

Freud, S. (2011). Wstęp do psychoanalizy. Warszawa: Hachette.

Fricton, J. R., Kroening, R., Haley, D., \& Siegert, R. (1985). Myofascial pain syndrome of the head and neck: a review of clinical characteristics of 164 patients. Oral Surgery, Oral Medicine, Oral Pathology, 60, 615-623.

Gamsa, A. (1990). Is emotional disturbance a precipitator or a consequence of chronic pain? Pain, 42, 105-111.

Biegańska-Banaś Józef K. Gierowski Ewa Ferendiuk Małgorzata Pihut Katarzyna Adamczyk

Glaros, A. G., Williams, K., \& Lauste, L. (2005). The role of parafunctions, emotions and stress in predicting facial pain. Journal of the American Dental Association, 136, 451-458.

Golchai, J., Khani, S. H., Heidarzadeh, A., Eshkevari, S. S., Alizade, N., \& Eftekhari, H. (2010). Comparison of anxiety and depression in patients with acne vulgaris and healthy individuals. Indian Journal of Dermatology, 55, 352-354.

International Association for the Study of Pain (1994). Classification of chronic pain: descriptors of chronic pain syndromes and definitions of pain terms. 2nd ed. Seatle: IASP Press.

Inglehart, M. R, \& Bagramian, R. A. (2002). Oral health-related quality of life: an introduction. In: Inglehart, M. R. \& Bagramian, R. A. (Eds.), Oral health related quality of life (pp. 1-6). Chicago: Quintessence.

Kahneman, D., Slovic, P., \& Tversky, A. (Eds.). (1982). Judgment under uncertainty: Heuristics and biases. New York: Cambridge University Press.

Kałwak, W. (2011). Metody jakościowe w badaniu bólu - doniesienie z badań. Rocznik Kognitywistyczny, 5, 73-81.

Kino, K., Sugisaki, M., Haketa, T., Amemori, Y., Ishikawa, T., Shibuya, T., ...Miyaoka, H. (2005). The comparison between pains, difficulties in function, and associating factors of patients in subtypes of temporomandibular disorders. Journal of Oral Rehabilitation, 32, 315-325.

Künsbeck, H.W., Korber, J., \& Freyberger H. Quality of life in patients with inflammatory bowel disease (1990). Psychotherapy and Psychosomatics, 54, 110-116.

Kwan, B. M., Dimidjian, S., \& Rivzi, S. L. (2010). Treatment preference, engagement and clinical improvement in pharmacology versus psychotherapy for depression. Behaviour Research and Therapy, 48, 799-804.

Laskin, D. M. (1969). Etiology and the pain-dysfunction syndrome. Journal of the American Dental Association, 79, 147-153.

Lautenbacher, S., \& Fillingim, R. B. (2004). Pathophysiology of Pain Perception. New York: Kluwer Academic/Plenum.

Locker, D. (1988). Measuring oral health: A conceptual framework. Community Dental Health, 5, 3-18.
Locker, D., \& Slade, G. D. (1993). Oral health and the quality of life among older adults: the oral health impact profile. Journal of Canadian Dental Association, 59, 837-844.

Łazowski, J. (1989). Psychologiczne aspekty patogenezy bólu. Przegląd Lekarski, 46, 415-419.

Makowiec-Dąbrowska, T., Koszada-Włodarczyk, W., Bartkiewicz, A., Gadzicka, E., Siedlecka, J. (2009). Can heaviness of the work for woman be the same as men? Medycyna Pracy, 60, 469-482.

Maslow, A. (2013). A Theory of Human Motivation. Floyd: Wilder Publications.

Melzack, R., \& Casey, K. L. (1968). Sensory motivational and central controlled determinants of pain: A new conceptual model. In: K. Shalod (Ed.), The skin senses (pp. 423-443). Springfield, IL: Charles C. Thomas.

Mongini, F., \& Italiano, M. (2001). TMJ disorders and myogenic facial pain: a discriminative analysis using the McGill pain questionnaire. Pain, 91, 323-330.

Mutlu, N., Herken, H., Güray, E., Öz, F., \& Kalayci, A. (2002). Temporomandibular Joint Disorder Syndrome in Dental School Students with Psychometric Analysis. Turkish Journal of Medical Sciences, 32, 345-350.

Naliboff, B. D., \& Cohen, M. J. (1989). Psychophysical laboratory methods applied to clinical pain patients. In: C. R. Chapman \& J. D. Loeser (Eds.), Issues in Pain Measurement. Advances in Pain Research and Therapy. Vol. 12. (pp. 356-386). New York: Raven Press.

Nunberg, H. (1968). Principles of psychoanalysis, Their Application to the Neurosis. 1st ed. (pp. 53-113). New York: International Universities Press.

Okeson, J. P. (2014). Bell's Oral and Facial Pain. 7th ed. Chicago: Quintessence Publishing Co, Inc.

Oliveira, A. S. (2005). Evaluation of quality of life and pain in Temporomandibular Disorders (TMD). Brazilian Journal of Oral Sciences, 12, 646-650.

Oliveira, A. S., Bermudez, C. C., Souza, R. A., Souza, C. M. F, Castro, C. E. S, Bérzin, F. (2003a). Avaliação multidimensional da dor em portadores de desordem temporomandibular utilizando uma versão brasileira do questionário McGill de dor. Revista Brasileira de Fisioterapia, 7, 151-158.

Oliveira, A. S., Bermudez, C. C., Souza, R. A., Souza, C. M. F, Dias, E. M., Castro, C. E. S., Bérzin, F. (2003b). Pain impact on life of patients with temporomandibular disorder. Journal of Applied Oral Science, 11, 138-143.

Omeje, O., \& Chinenye, N. (2011). The Influence of Locus Control on Adherence to Treatment Regimen among Hypertensive Patients. Patient Preference and Adherence, 5, 141-148.

Oosterhof, N. N., \& Todorov, A. (2008). The functional basis of face evaluation. Proceedings of the National Academy of Sciences of the United States of America, 105, 11087-11092. 
Ortenburger, D. (2008). Czynniki psychologiczne w bólu przewlekłym. Częstochowa: Wydawnictwo im. Stanisława Podobińskiego Akademii im. Jana Długosza w Częstochowie.

Öztürk, A., Dveci, E., Bağcioğlu, E., Atalay, F., \& Serdar, Z. (2013). Anxiety, depression, social phobia, and quality of life in Turkish patients with acne and their relationships with the severity of acne. Turkish Journal of Medical Sciences, 43, 660-666.

Patel, K. A., \& Schlundt, D. G. (2001). Impact of moods and social context on eating behavior. Appetite, 36, 111-118.

Peters, M. L., Schmidt, A. J. M., Van den Hout, M. A., Koopmans, R., \& Sluijter, M. E. (1992). Chronic back pain, acute postoperative pain and the activation of diffuse noxious inhibitory controls (DNIC). Pain, 50, 177-187.

Pihut, M., Gierowski, J. K., Ceranowicz, P., \& Ferendiuk, E. (2015). Psychoemotional Background of Temporomandibular Joint Dysfunction and Possible Drug Therapy. Letters in Drug Design \& Discovery, 12, 766-770.

Pihut, M., Szewczyk, M., Wiśniewska, G., \& Gala A. (2012). Ocena przydatności kwestionariusza McGilla-Melzacka w diagnostyce doznań bólowych u pacjentów z zaburzeniami czynnościowymi układu stomatognatycznego - doniesienia wstępne. Protetyka Stomatologiczna, 2, 70-75.

Prusiński, A. (1996). Kliniczne postacie bólu. In: T. Domżał (Ed.), Ból - podstawowy objaw w medycynie (pp. 78-149). Warszawa: Wydawnictwo Lekarskie PZWL.

Reisine, S. T., \& Weber, J. (1989). The effects of temporomandibular joint disorders on patients' quality of life. Community Dental Health, 6, 257-270.

Resende, C. M., de Medeiros, A. C., Coelho, L. T., Alchieri, J. C., Roncalli, A. G., \& Seabra Barbosa, G. A. (2013). Quality of life and general health in patients with temporomandibular disorders. Brazilian Oral Research, 27, 116-121.

Richter, P., \& Hebgen, E. (2010). Punkty spustowe $i$ tańcuchy mięśniowo-powięziowe w osteopatii i terapii manualnej. Łódź: Galaktyka.

Rugh, J. D., Woods, B. J., \& Dahlstrom, L. (1993). Temporomanidubular disorders: assessment of psychological factors. Advances in Dental Research, 7, 127-136.

Schipper, H., Clinch, J. J., \& Olweny, C. L. M. (1996). Quality of life studies: definitions and conceptual issues. In: W. B. Spilker (Ed.), Quality of Life and Pharmacoeconomics in Clinical Trials (pp. 11-23). Lippincott-Raven Publishers: Philadelphia.

Schwartz, L. (1959). Disorders of the temporomandibular joint. Philadelphia: W.B. Saunders.

Schwartz, M. B., \& Brownell, K. D. (2004). Obesity and body image. Body Image, 1, 43-56.

Shahraki, N., Yassaei, S., \& Goldani, M. (2012). Abnormal oral habits: A review. Journal of Dentistry and Oral Hygiene, 4, 12-15.
Simons, D. G., Travell, J. G., \& Simons, L. S. (1999). Head and neck pain. In: J. G. Travell \& D. G. Simons (Eds.), Myofascial Pain and Dysfunction: The Trigger Point Manual. 2nd ed. (pp. 237-483). Baltimore: Williams and Wilkins.

Sischo, L., \& Broder, H. L. (2011). Oral Health-related Quality of Life: What, Why, How, and Future Implications. Journal of Dental Research, 90, 12641270.

Slade, G. D., \& Spencer, A. J. (1994). Development and evaluation of the Oral Health Impact Profile. Community Dental Health, 11, 3-11.

Slade, G. D., Spencer, A. J., Locker, D., Hunt, R. J., Strauss, R. P., \& Beck, J. D. (1996). Variations in the social impact of oral conditions among older adults in South Australia, Ontario, and North Carolina. Journal of Dental Research, 75, 1439-1450.

Styczyński, T. (2001). Problemy terapeutyczne związane z przewlekłym bólem i zaburzeniami napięcia mięśniowego u chorych na dyskopatię lędźwiowego odcinka kręgosłupa. Reumatologia, 39, 390-394.

Suchocka, L. (2008). Psychologia bólu. Warszawa: Wydawnictwo Difin.

Svensson, P., \& Graven-Nielsen, T. (2001). Craniofacial muscle pain: review of mechanisms and clinical manifestations. Journal of Orofacial Pain, 15, 117-145.

Szatanik, K. (1985). Kwestionariusz bólowy - założe nia, budowa kwestionariusza, wyniki przeprowadzonych badań. V Konferencja Sekcji Badania i Leczenia Bólu Polskiego Towarzystwa Anestezjologii i Intensywnej Terapii. Poznań - Błażejewko.

Thaller, V., Vrkljan, M., Hotujac, L., \& Thakore, J. (1999). The potential role of hypocortisolism in the pathophysiology of PTSD and psoriasis. Collegium Antropologicum, 23, 611-619.

Tobiasz-Adamczyk, B. (1996). Jakość życia w naukach społecznych i medycynie. Sztuka leczenia, 2, 33-40.

Tobiasz-Adamczyk, B. (2000). Wybrane elementy socjologii zdrowia i choroby. Kraków: Wydawnictwo Uniwersytetu Jagiellońskiego.

Tobiasz-Adamczyk, B. (2006). Geneza zdrowia, koncepcji i ewolucja pojęcia jakości życia. In: K. Kawecka-Jaszcz, M. Klocek \& B. Tobiasz-Adamczyk (Eds.), Jakość życia w chorobach układu sercowo-naczyniowego. Metody pomiaru i znaczenie kliniczne (pp. 9-42). Poznań: Termedia.

Travell, J. G., \& Simons, D. G. (1983). Myofascial Pain and Dysfunction: The Trigger Point Manual. Baltimore, MD: Williams \& Wilkins.

Van Grootel, R. J., Van der Glas, H. W., Buchner, R., de Leeuw, J. R., Passchier, J. (2005). Patterns of pain variation related to myogenous temporomandibular disorders. Clinical Journal of Pain, 21, 154-165.

Vernon, R. J. W., Sutherland, C. A. M., Young, A. W., \& Hartley, T. (2014). Modeling first impressions from
Psychology of TMJPDS 
highly variable facial images. Proceedings of the National Academy of Sciences of the United States of America, 111, E3353-E3361.

Vickers, E. R., \& Boocock, H. (2005). Chronic orofacial pain is associated with psychological morbidity and negative personality changes: a comparison to the general population. Australian Dental Journal, 50, 21-30.

Von Korff, M. (1999). Pain management in primary care: An individualized stepped-care approach.

Joanna M. Biegańska-Banaś Józef K. Gierowski

Ewa Ferendiuk Małgorzata Pihut Katarzyna Adamczyk In: R. J. Gatchel \& D. C. Turk (Eds.), Psychosocial factors in pain (pp. 360-373). New York: Guilford Press.

Voss, R. (1964). Behandlung von beschwerden des kiefergelenkes mit aufbissplatten. Deutsche Zahnärztliche Zeitschrift, 19, 545-549.

Wright, E. F. (2000). Referred craniofacial pain patterns in patients with temporomandibular disorder. Journal of the American Dental Association, 31, 1307-1315.

Watanabe, Y., Ishikawa, T., Kino, K., Yamaguchi S., Kobayashi A., Sawada M., ...Amagasa T. (2005). Relationship between oral sensory thresholds and depressive moods. Journal of Medical and Dental Sciences, I52, 73-80.

WHOQOL Group (1995). The World Health Organisation quality of life assessment (WHOQOL): Position paper from the world health organisation. Social Science \& Medicine, 41, 1403-1409.

Ziółkowska, B. (2009). Dlaczego (nie)jemy? Psychologiczne uwarunkowania stosunku do pokarmu. In: B. Ziółkowska (Ed.), Opętanie (nie)jedzeniem (pp. 177-186). Warszawa: Wydawnictwo Naukowe Scholar.

Ziółkowska, B., \& Mroczkowska, D. (2012). Dlaczego jemy? Uwarunkowania stosunku do jedzenia w cyklu życia na podstawie analizy wyników wstępnego sondażu. Teraźniejszość - człowiek edukacja, 4, 1-14. 